\title{
Urban development criteria with a focus on resilience to pandemics: a case study of Corona Virus (Covid-19)
}

Elham Zabetian Targhi ( $\square$ ezabetian@yahoo.com )
Building and Housing Research Center

Niusha Fardnava

Islamic Azad University Central Tehran Branch

Saba Saghafi

Islamic Azad University South Tehran Branch

\section{Research Article}

Keywords: Urban Resilience, Pandemics, Corona Virus (Covid-19), Criteria

Posted Date: May 10th, 2021

DOI: https://doi.org/10.21203/rs.3.rs-326544/v1

License: (c) (i) This work is licensed under a Creative Commons Attribution 4.0 International License. Read Full License 


\section{Abstract}

Urban resilience to Corona Virus and its globalization has become a major concern for cities these days. The spread of the Corona Virus (Covid-19) pandemic began in early 2020 and gradually spread throughout the world. This pandemic affected all aspects of the individual and social life of the inhabitants of the planet. Our country also has not been safe from the destructive effects of this virus in social, welfare, economic, physical, governance, and management dimensions; and according to official statistics, hundreds of thousands of people in Iran have been infected with this virus and tens of thousands have died so far.

Therefore, to measure urban resilience to this pandemic, some criteria and sub-criteria were developed based on the authors' documentary and field studies, and their significance or weights were determined using analytical-comparative research method using a questionnaire of paired or L-hour comparisons from the viewpoint of experts in urban sciences and urban development using AHP hierarchical analysis in EXPERT CHOICE software. Then, designing a questionnaire with a five-point Likert scale, the satisfaction of Tehran residents with the extracted criteria and sub-criteria was measured and the correlation between the important criteria in each dimension was assessed using correlation tests in SPSS16 software.

According to the obtained results of AHP analysis and the scores of each sub-criterion, the weight of all criteria was normal. In the next stage, according to the pairwise correlation tests between the important criteria in each dimension from the viewpoint of urban science experts and Tehran residents, it was concluded that the reliability of the correlation between the criteria is $99 \%$. In all the cases, the P-value or the same significance level was less than 0.05 , which indicated the significance of the pairwise relations between the variables.

\section{Introduction}

In recent decades, the increase in the world population especially in urban areas as an important phenomenon has created many complexities and problems in various fields. Meanwhile, the field of risks is one of the most important issues in the area of urban planning and design for crisis and risk management, reducing risks and injuries, increasing safety, and quality of life. The city is very important as the scene of events. Therefore, planning, recognizing urban spaces, and their proper design are ways to meet various needs of citizens in the three dimensions of prevention, response, and post-crisis measures. So, when dealing with crises in urban planning and design, paying attention to the principle of flexibility as one of the factors in creating high quality and resilient urban space enables the space to provide several options at any time to deal with and reduce risks and effects of the crisis for the citizens (Fallah et al.: 2014: 1354).

This uncontrolled and rapid population growth has made urbanization one of the main risk factors. Also, given that cities are centers of diverse economic and social activities, they are very vulnerable to natural hazards (Parvin et al., 2016: 21). Therefore, one of the major problems faced by most of the world's metropolises is natural hazards that always threaten human settlements and lives, and in a short time can cause extensive damage and loss (Sasanpour and Musavand, 2010: 29).

Accordingly, today's urban societies, especially developing societies, face a complex range of social, environmental, economic, etc. challenges against natural hazards. In many of these communities, new approaches are needed to cope with these challenges (Grimmond, 2007: 84).

Cities and settlements have been created or built in places that are prone to various natural disasters or man-made disasters due to technological advances. The approach to disaster management and urban management so far has been mostly a confrontation and risk reduction approach. Meanwhile, the concept of resilience is a new concept that is mostly used in the face of unknowns and uncertainties (Farzad Behtash et al., 2013: 33).

\section{Materials And Methods}

The present study seeks to answer two basic questions: what are the criteria and sub-criteria affecting the realization of urban resilience to Covid-19 in Tehran and how much is the significance and weight of each of these cases from the perspective of 
urban science experts such as urban designers and planners and citizens? How is the correlation between these criteria? So, the following steps have been taken to answer the above questions:

First, through documentary studies, while reviewing the literature on the subject, using the analytical-comparative method, the significance of the 12 criteria and 36 sub-criteria extracted according to the theories of various urban intellectuals and experts was measured. The selected experts were urban managers, consulting engineers, contractors, and university professors who were experienced and knowledgeable about urban projects in the field of urban planning and design in Tehran. The selection of these experts was based on purposeful sampling and finally, 16 experts were selected to complete the pairwise comparison (Lhour) questionnaire. The results of experts' opinions using the AHP hierarchical analysis method in EXPERT CHOICE software have been used to score the criteria and sub-criteria in the study, the result of which can be seen in the score column in Table 5 . It should be noted that the sum of scores of the sub-criteria of each criterion was equal to one which indicates the normality of the weight of the sub-criteria to continue studies in the field.

In the next step, to prioritize and measure the significance of the criteria and sub-criteria from the viewpoint of Tehran citizens, a questionnaire including questions related to the extracted criteria was prepared and valued using a five-point Likert scale. This questionnaire was completed based on purposeful sampling by 120 people who were selected completely randomly. Finally, by analyzing the data obtained from the questionnaires, using the pairwise correlation test in SPSS 16 software, the correlation between the criteria of each dimension was measured.

\section{Theory (Concepts And Theoretical Foundations)}

\section{1. Resilience}

The concept of resilience means the ability to resist or adapt to various shocks, pressures, and stresses, which has been widely used in urban studies (Vanolo, 2015: 1).

The term resilience has a very long history and its use dates back to at least a century before Christ (Alexander, 2013: 2708). But the concept of resilience in the modern era (the 1970s) goes back to the General System Theory and first began by Crawford Stanley Holling. Holling (1973) defines resilience as an indicator of system continuity and its ability to absorb change and maintain the relationship between groups of society in different ecological systems. Since then, the term has been used and applied in almost all disciplines, languages, institutions, as well as in different cities and regions (Garschagen, 2013: 27). Today, the concept of resilience has entered the field of planning with different orientations (social, economic, physical, managerial, etc.), although most of its attention is still focused on environmental issues and a large part of its discoveries is about the management of environmental hazards such as earthquakes, floods, hurricanes, and global warming (Pizzo, 2015: 134).

The concept of resilience has been defined in various ways, and several conceptual circles have been formed from it. However, there is a comprehensive conceptual agreement on this issue. According to Alberti et al., whose definition of resilience has been

widely cited in scientific studies, resilience is "the degree to which a system can absorb risks and reorganize itself". Accordingly, resilience is a combination of "disorder absorption and achieving equilibrium", "self-reorganization" and "increasing learning and adaptation capacity" (Alberti, et al., 2003).

Numerous definitions of resilience have been proposed so far, but due to its widespread use in various sciences, a comprehensive definition of resilience has not yet been provided. Table 1 shows some of the definitions of resilience and Table 2 shows the definitions of resilience in different sciences.

\section{Table 1: Definitions of resilience in different sources}




\begin{tabular}{|c|c|}
\hline $\begin{array}{l}\text { Mileti } \\
(1999)\end{array}$ & $\begin{array}{l}\text { Resilience means that the community can withstand severe natural disasters without facing major } \\
\text { damages, injuries, cessation of production, or reduced quality of life and without receiving much help from } \\
\text { outside the community. }\end{array}$ \\
\hline $\begin{array}{l}\text { Adger } \\
(2000)\end{array}$ & $\begin{array}{l}\text { It is the power of groups and communities to adapt to external pressures and the destructions that result } \\
\text { from social, political, and other changes. }\end{array}$ \\
\hline $\begin{array}{l}\text { Pelling } \\
(2003)\end{array}$ & The ability of a social agent to cope with or adapt to risky tensions. \\
\hline $\begin{array}{l}\text { Paton et al. } \\
(2001)\end{array}$ & $\begin{array}{l}\text { Resilience is an active process of self-correction, conscious provision of resources, and growth; the ability to } \\
\text { create psychological structures to a level beyond the expected individual ability and past experiences. }\end{array}$ \\
\hline $\begin{array}{l}\text { Timmerman } \\
(1981)\end{array}$ & Resilience is the capacity of a system or part of it to absorb and recover after a hazardous event. \\
\hline $\begin{array}{l}\text { Buckle et al. } \\
(2000)\end{array}$ & $\begin{array}{l}\text { The quality of people, communities, agencies, and infrastructures reduces vulnerability. It is not only the } \\
\text { lack of vulnerability but also the capacity to prevent and reduce damages and then, in the second place, in } \\
\text { the event of damage, to maintain ideal conditions in the community as much as possible, and then in the } \\
\text { third place to recover from the effects. }\end{array}$ \\
\hline
\end{tabular}

Source: (Rezaei, 2010: 27)

A clear example of urban resilience characteristics is the sample developed as part of the United Nations City Resilience Profiling Tool (CRPT, 2018) and is a general guide to a variety of inconsistencies and events. In conceptualizing their framework, the team in the UN-Habitat (ibid.: 21) uses 10 important factors in creating resilience in the city. These important factors are known as holistic measures to include a wide range of considerations (Cheshmehzangi, 2020: 49).

The first factor is that the urban resilience framework should be "measurable" and show the "tangible and intangible realities" that can be converted into qualitative and quantitative data. The second factor is "urban systems", which are defined as complex parts of integrated and complex systems, consisting of parts, people, and risks, and are managed through effective mechanisms. The third factor is considering "residents"; all people who live, work, visit, or travel to the city just as we as institutions, organizations, businesses, etc., life or have relations with each other. The fourth factor is the importance of "cohesion", including maintaining support and services, financial flows, and structures, to save people's lives (Cheshmehzangi, 2020: 49).

The fifth factor is known as a response to pressures and overcoming "shocks and stresses". These are identified as situations with hazards for the city and those that may be "sudden and slowly destructive, natural or man-made, rare and orderly, predictable or unpredictable". The sixth factor is the major focus on "transformation", which refers more to examples of "taking an active and forward-looking attitude that turns challenges into opportunities for growth". This means methods of progress in transformations that can change the situation by creating incremental transformations and support. The seventh factor is recognition of "sustainability" and its methods including a wide range of factors of community development, innovations, economic production, and service support. The seventh factor is the importance of access, which refers to what ultimately creates a wide range of actions, guidelines, and recommendations; practically applicable cases. Finally, these eight factors lead to two important factors: "planning" and "action". Using appropriate planning methods, we can create effective strategies and strengthen the city to deal with a wide range of vulnerabilities and strengthen the capacity for effective and efficient performance; and through actions, we can provide reliable and constructive assessments to support strategic planning and respond to the situation (Cheshmehzangi, 2020: 50).

\subsection{Urban resilience}

In the most recent definition of urban resilience in recent studies, it refers to the capabilities of an urban system and all its constituting socio-ecological and socio-technical networks at temporal and spatial scales that in the face of disruptions maintain desirable performances or return to them quickly; a system that is adaptable to change, and if the system limits the capacity to adapt to current or future changes, it is rapidly changed and transformed by the resilience feature (Meerow, Newell, \& Stults, 2016). 


\begin{tabular}{|ll|}
\hline Sciences & Definitions \\
\hline Ecological & $\begin{array}{l}\text { Measurement of the system's ability to absorb changes; the speed at which a system returns to its original } \\
\text { state; the capacity of a system to absorb turbulence and reorganize; the ability of a system to withstand } \\
\text { pressure; the amount of turbulence that a system can absorb and remain in the same state. }\end{array}$ \\
\hline $\begin{array}{l}\text { Socio- } \\
\text { ecological }\end{array}$ & $\begin{array}{l}\text { Learning to live despite changes and uncertainties; diversity increases the ability to learn from disasters; } \\
\text { combining different types of knowledge to learn; creating opportunities for self-organization. }\end{array}$ \\
\hline Social & $\begin{array}{l}\text { The ability of groups or communities to adapt to external tensions and turmoil; the ability of social units to } \\
\text { reduce risks; conducting recovery activities to reduce social disruption; the ability to take advantage of } \\
\text { opportunities. }\end{array}$ \\
\hline Economics & $\begin{array}{l}\text { The inherent response and adaptation of individuals and communities to hazards enable them to reduce the } \\
\text { losses of potential harms resulting from hazards. }\end{array}$ \\
\hline Psychology & $\begin{array}{l}\text { The ability of an individual to walk away and retreat in the face of disasters and accidents; the capacity for } \\
\text { successful adaptation; positive performance following prolonged and severe shocks. }\end{array}$ \\
\hline $\begin{array}{l}\text { Basic } \\
\text { science }\end{array}$ & $\begin{array}{l}\text { The ability to store the pressure's energy and elasticity under a load that bends without breaking or } \\
\text { deforming; the speed at which a system returns to equilibrium after displacement regardless of the required } \\
\text { fluctuation. }\end{array}$ \\
\hline
\end{tabular}

Source: (Rafieian et al., 2011: 23)

Urban resilience is a relatively new concept that still lacks a clear definition (Jabareen, 2012). The definition of urban resilience generally refers to the ability of a city or urban systems to withstand a wide range of shocks and stresses (Agudelo-vero et al., 2012). This shows that urban resilience ensures not only a system of returning to the past state of equilibrium but also the possibility of adapting to changes and further survival of the city in the future (Folke, Carpenter, et al., 2010).

Arefi (2011) argues that different areas of the city show different spectra of resistance to changes. In cities, these changes are often caused by economic, cultural, and technological conditions (Arefi, 2014).

One of the benefits of planning for urban resilience is that there is no need to focus on a specific pattern of urban form or urban development. This flexibility allows for responsiveness and adaptability given the unique circumstances of cities and development plans. This leads to intellectual creativity to think about different ways of achieving resilience without being limited to a specific framework (Turner, 2013).

The Subcommittee on Disaster Reduction (SDR, 2005) describes the characteristics of resilient cities as follows:

- Appropriate and relevant hazards are identified and understood.

- Resilient cities know when danger is imminent.

- People are safe from hazards.

Resilient societies experience minimal disruption in the course of their lives and economies after disasters (Solecki, Leichenko, et al., 2011).

\section{Table 3: Characteristics of resilient cities}




\begin{tabular}{|c|c|c|c|c|}
\hline No. & Component & Concept & Promoting factors & Goal \\
\hline 1 & Stability & $\begin{array}{l}\text { Safe and valid, } \\
\text { tolerable, reliable }\end{array}$ & $\begin{array}{l}\text { The system having security factors and protection } \\
\text { against shocks, the ability to change the decision chain } \\
\text { in the face of crisis }\end{array}$ & $\begin{array}{l}\text { Preventing } \\
\text { the } \\
\text { transmission } \\
\text { of damage } \\
\text { to other } \\
\text { sectors }\end{array}$ \\
\hline 2 & Redundancy & $\begin{array}{l}\text { Having adequate } \\
\text { excess and } \\
\text { precautionary } \\
\text { storage capacity }\end{array}$ & $\begin{array}{l}\text { Having excess capacity in sensitive infrastructures and } \\
\text { being equipped with a variety of solutions and strategies } \\
\text { to solve a problem }\end{array}$ & $\begin{array}{l}\text { Maintaining } \\
\text { system } \\
\text { operation }\end{array}$ \\
\hline 3 & $\begin{array}{l}\text { Consciousness } \\
\text { and prudence }\end{array}$ & $\begin{array}{l}\text { The ability to adapt } \\
\text { and being cautious }\end{array}$ & $\begin{array}{l}\text { Increasing trust within the system and the ability of the } \\
\text { components to self-organize }\end{array}$ & $\begin{array}{l}\text { Being } \\
\text { prepared for } \\
\text { adaptation } \\
\text { and revival }\end{array}$ \\
\hline 4 & $\begin{array}{l}\text { Responding to } \\
\text { hazards }\end{array}$ & $\begin{array}{l}\text { The ability of the } \\
\text { community to move } \\
\text { quickly, the ability to } \\
\text { decide for } \\
\text { reorganization at a } \\
\text { given time in times } \\
\text { of crisis }\end{array}$ & Effective communication and inclusive participation & $\begin{array}{l}\text { Adaptability } \\
\text { to new } \\
\text { conditions }\end{array}$ \\
\hline 5 & Revival & $\begin{array}{l}\text { Adaptability, } \\
\text { correcting the } \\
\text { situation, and } \\
\text { restoration }\end{array}$ & $\begin{array}{l}\text { Increasing the capacities and strengthening the } \\
\text { strategies, information, and knowledge in } \\
\text { implementation of public and business policies, and the } \\
\text { ability of decision-makers to update given the changes in } \\
\text { environmental conditions, discovering knowledge gaps } \\
\text { and then organizing research to fill those gaps }\end{array}$ & $\begin{array}{l}\text { Returning } \\
\text { the system } \\
\text { to its normal } \\
\text { operation } \\
\text { after a crisis }\end{array}$ \\
\hline
\end{tabular}

(McEntire, 2014)

\subsection{Dimensions of urban resilience}

To measure the resilience of cities against risks such as pandemics, first, the dimensions and components of urban resilience should be recognized.

The ecological resilience perspective has been adopted from a wide range of fields including anthropology, environmental psychology, cultural theory, economics, management, and organizational sociology (Folke, 2006: 255). This model of resilience focuses on the stability of conditions despite changes and unpredictability (King, 2008: 114).

Among the dimensions of resilience, the economic dimension is one of the most important. According to recent topics in engineering and economics, measurement of economic structures is possible through the identification of weaknesses of the economic system to increase economic resilience caused by human and natural disasters (Martinelli et al., 2014: 961). Therefore, economic resilience is evaluated based on the severity and extent of the damage, the capacity or ability to compensate the damages and the ability to return to appropriate employment and income conditions, the amount of household capital and incomes convertible into capital and employment, housing status, access to financial services, insurance, allowances and the ability to revive economic activities of households after an accident. This dimension of resilience increases or reduces economic stability, especially livelihood stability in the community (Rezaei, 2014, 27).

In different studies, different descriptions of the concept of social resilience have been obtained and the definitions of it have been relatively personal and free (Kulig, 2000: 375). But in general, social resilience has been defined as the ability of a social institution (a group or society) to leap backward or respond positively to hardships and disasters (Almedom, 2005: 253).

The concept of organizational resilience is defined as the ability of an institution or organization to adapt to the conditions of the surrounding environment and the ability to create redevelopment capability to absorb and manage environmental changes. Therefore, in the literature on organizational resilience, it is assumed that crises (system disruptions) occur in the natural 
course of an organization. Here, the important thing is organizational readiness in terms of strategy, operations, and concentrated structure (Ayling, 2009: 84).

A resilient city is a stable network of physical systems and human communities. Physical systems are the environmental and built-up components of a city, including roads, buildings, infrastructures, communication facilities, soil, geographical features, and the like. In general, physical systems act as the body, the bones, and the arteries of a city. In the event of an accident, physical systems must be able to survive and function in critical conditions (Godschalk, 2003: 136).

\subsection{Resilience and pandemics}

At the times of pandemics, there is a need for more urban resilience than the strategic resilience plan. As mentioned earlier, when pandemics occur the conditions are indescribable and exclusive responses are required. This became apparent some years ago when we developed the first resilient city tool (Siemens, Arup, and RPA, 2013).

Through various studies on resilient cities and urban resilience measures, we can examine a wide range of direct impacts on health, emergency medical services, communities, infrastructures, economics and businesses, reliability, production systems, social welfare, and quality of life. Since much of the city's structure is deteriorating rapidly, we must ensure that the city is sufficiently prepared to manage the situation before it can make progress (Cheshmehzangi, 2020: 8).

For the measures to be effective, urban resilience requires pioneering thinking. Besides, there is certainly a need to support guidelines and frameworks (Ihekweazu, et al., 2010).

To date, there is little specific literature on urban resilience during pandemics. On the other hand, there are general examples of practical measures, frameworks, tools, and guidelines that enable us to support the cities in need. In practice, however, urban officials often need to make decisions quickly and accurately. These decisions must be specific in content and address cultural factors, social needs, and economic concerns about that particular city or place. This process is so effective that it can cause significant change and disruption in any direction. Any decision must be made carefully before it is made available to the public, otherwise, it can turn into various media games from social media to international media. They can make fake news, increase anxiety and fear, and simply create pandemonium (Cheshmehzangi, 2020: 9).

At the time of pandemics, many public health issues require a new (or modified) perspective. Hence, when pandemics occur in cities and urban communities, vulnerabilities are much higher. Undoubtedly, resilience is necessary for every event and in every society. Most importantly, we also individually and socially, as a part of society must acquire resilience skills. However, the likelihood of failures in skills is high, and reconsideration and regretting from these decisions and skills can take much time and inhibit progress, and interrupt the recovery at any time (Cheshmehzangi, 2020: 9).

In general, urban resilience should be realized as the backbone of how cities are managed effectively and profitably, especially in the event of pandemics. There is little preparation (which does not include limited services, equipment, and facilities) before the actual outbreak begins. So, most tasks are not necessarily related to preparedness but are immediate and strategic responses that must be developed, outlined, and implemented during pandemics. This is just why at times of pandemics like some catastrophic events vulnerabilities are so high and cities and communities are at a dangerous level of risk (Cheshmehzangi, 2020: 9).

WHO (2019: 15) indicates in its reports that, while guidance in the management of pandemics and responding to outbreaks is clear, but the health sector also has a critical role in preventing and minimizing health consequences in emergencies due to natural, technological and social hazards. In addition to this report, it is important to note that from the perspective of urban management, different sectors should experience the same situation; other sectors related to such incidents intend to respond quickly and appropriately to the emergencies and disruptions resulting from these special events.

In other words, the city as a whole becomes a creature that needs to deal with emergencies at several different levels and sectors. By having a resilience plan (for example, in any action-based performance), the city can act more effectively in managing specific events and their negative effects on society (Cheshmehzangi, 2020: 10).

Page $7 / 18$ 
Hence, it is suggested to strengthen urban resilience where we can and where it seems to be possible in certain circumstances (e.g. economic capacities, capabilities, economic background, social issues, etc.). With such a planning approach, we can accelerate the processes of controlling and recovering from pandemics_that is, better management of the spread of the disease and preventing it from turning from an emergency to a disaster (Cheshmehzangi, 2020: 10).

Finally, what needs to be considered is the method of preparation and response in a process. This requires a framework that can be effective in the existing changing situation at the time of pandemics. Therefore, a fundamental action with responsibility by government officials (from several departments), emergency units and emergency medical services, and other related stakeholders of the public sector, private bodies, non-governmental organizations, NGOs, community groups and the public is essential. This situation creates new management and operational ecosystem that requires resilience measures and adaptive capacities (Cheshmehzangi, 2020: 10).

These factors, in addition to having adequate planning measures, require a tangible resilience capacity to be able to effect quickly, prepare, and respond to situations in the best possible way (Cheshmehzangi, 2020: 10).

\subsection{Cities at the time of pandemics}

At all stages of pandemics, cities can suffer greatly and society may need to endure some of these negative effects for some time. However, from a positive perspective, new opportunities have arisen to strengthen urban resilience and urban management (Hrudey et al., 2002).

Besides, it is clear that during pandemics, we are faced with a wide range of vulnerabilities, as well as a wide range of affected local groups and individuals who can be even more vulnerable than other local groups and individuals. In most pandemics, depending on their mortality rate and the quality of their response to control and treatment measures, we can identify three distinct categories of vulnerable/local groups that may suffer the most:

- People who are unaware of the conditions and, for any reason, do not know may be infected or may have the disease/virus. Hence, their delayed response or action at the latest stages may lead to the progression of the disease in their body.

- Those vulnerable sections of the society who are less resistant to diseases/ viruses/ infections, including the elderly, those with previous health conditions, or those prone to high health risks.

- Those communities, cities, and even countries that lack health infrastructures and poorer resilience, or those with limited resources and insufficient equipment, emergency units, diagnostic and confirmation tools, medical personnel, and related equipment (Cheshmehzangi, 2020: 32).

The above-mentioned vulnerable groups represent a wide range of groups, from individuals to larger scales of cities or countries (or their clusters). Hence, during pandemics, the alert level rises to a higher level if it spreads or concentrates in poorer countries or areas with minimal health infrastructures/ systems and many other related factors that indicate a more vulnerable location. Therefore, we must consider vulnerable groups and individuals as the first point of our resistance planning (Cheshmehzangi, 2020: 32).

\subsection{Step-by-step perspective of cities}

It is important to summarize how cities respond in the event of pandemics. It may seem that cities are operating normally and without any disruption or unexpected disruption. After searching for more information and using the official announcements that are made for pandemics, we finally find out that the performance of cities has changed a little. Usually, there are only minor effects. With the initial symptoms, we can see few people in public places, outdoors, shopping malls, and crowded areas of the city. As this stage progresses to a more alarming stage in the response stage, other sectors are also affected. The health care system and Emergency Medical Services (EMS) become more vigilant, and operational changes in cities increase with a higher speed. The public sector is affected the most because many public services gradually reduce their operations or may temporarily stop their tasks. It seems that in the use of public places, transportation in large-scale places, public transportation, 
and other public facilities have decreased further. In the next stage, namely the "transition phase", depending on the severity and scale of the pandemic, cities gradually prevent secondary operations. Hospitals and health clinics may become important points. So, they need more support to prevent the spread of the disease in those critical points. At this stage, cities will face major problems as most businesses, industries, and retail units may stop (or you may be asked to stop). If this happens, apart from the existing effects on society, its effects on the economy will also be more understandable. This will lead to more system failures as cities are facing more disruptions in their functions. At this stage, economic resilience and economic management are very significant for many critical infrastructures and key institutions under pressure. The economic foundation of cities suffers while the community worries about the rapid increase in cases and the mortality rate. At this stage, it is not necessary to close the city, but it may seem necessary if the response rate is not very fast in the early stages. This closing method can be partial to prevent negative effects on more parts. Eventually, the situation should become more stable, and it may end at this stage or peak at a later stage (Cheshmehzangi, 2020: 32-33).

The two-way "transition" phase usually begins with a moment of pause. This is a critical time for any city, as progress may change the direction. The pandemic could get worse, and this may cause the most damage to the city, as it can stop all operations and only health institutions and EMS can work. By stopping transportation, food systems and other industries become very vulnerable. If in the transition stage the pandemic has shown signs of improvement, then urban activities can begin slowly at the end of this stage. This process is gradually shifting so that the city slowly moves from an alert/emergency to a safer stage of improvement. In the transition phase, if the situation worsens, the pandemic can also change to a catastrophic state with higher risks than anticipated in the response phase. If this happens, the situation needs more support at various governmental levels and it may turn into a completely closed condition. If it did not happen sooner, this means significant impacts on almost all primary and secondary parts of the city. However, if the situation starts to improve in a stable pattern, the situation will approach the next stage of reduced pandemic (Cheshmehzangi, 2020: 33).

In the "recovery phase", cities must adopt and implement the maximum level of monitoring and control. For early inhibition, all operations must be stopped or monitored thoroughly and carefully. Cities should not take more risks and can compensate for more vulnerability. Recovery should succeed through full control of the pandemic. Any defect at this stage can potentially prolong the situation and intensify its prevalence, which will ultimately put more pressure on city officials and the entire city operations. After that, it becomes more difficult to maintain the adequate performance of various entities/ services. So, it is important to experience a temporary problem rather than long-term troubles. Once a stable state is established (after a certain period), then the operation may start gradually from the primary entities/ services to the secondary ones. This gradual change before achieving recovery must be carefully managed and the conditions must be under complete control. At this stage, the city must strengthen its health systems to ensure increased treatment opportunities and then support the overall process of treatment and recovery. When this happens, the situation gradually progresses toward full recovery of the pandemic. The path to this must be paved through high security, high supervision, a high level of risk management, and high resistance to any unexpected changes (Cheshmehzangi, 2020: 33-34).

With the success in the recovery phase, the community will begin to relax more. Finally, it is transferred to the final stage of "post-recovery". This occurs when regular operations of various departments, services, and extensive systems are visible. It is important that all progress can be seen as much as possible. Such an approach improves the sense of distress in the community and assures businesses and industries to plan for their regular activities. At this stage, cohesion is crucial in every aspect and all sectors, because a system in a healthier ecosystem of urban resilience and management can help another. Disorders are expected to be minimized during this stage, and the community needs the highest level of support to ensure initial recovery. At this stage, more public-oriented and community-oriented performance should shape and revive the overall operations of the city. Careful monitoring should remain in place to prevent any unexpected problems. By doing this, we will be able to return all departments to regular operations and maintain the conditions of all systems and services to their original regular patterns. In the last stage after the recovery, the city must resume its flexibility and maintain or improve its main institutions. Finally, the most important thing is the development of a "responsive urban management" (Cheshmehzangi, 2020: 34). 
In a broader sense, there are many theories about resilience and its applications (Carlson et al., 2012; Barrett and Constas, 2014).

But there is a significant difference between the theoretical aspects of resilience and how it develops in action planning (Coaffee, 2013; Coaffee and Lee, 2016; Cheshmehzangi, 2020a).

Through a better understanding of urban resilience (including a general overview of actions, applications, and practices) and multi-sector urban management, a program can be proposed for better responding to and preparedness for disasters and pandemics. From different urban examples, different tools, and different frameworks we learn how to address resilience and urban management from different perspectives or in different situations. Studying what can be done is not important alone, but how to do them in practice should also be studied (Cheshmehzangi, 2020: 34). The recent unpleasant pandemic of Covid-19 has inspired us to understand resilience from various perspectives, as most of these perspectives are related to the critical state of the pandemic. Most importantly, it is clear that resilience is a key, and city management is the ultimate answer to many functions (Cheshmehzangi, 2020: 35).

Resilience is scenario-based, but it is essential for the city, and how to get out of troubles, including pandemics, is one of those scenarios. Therefore, it is important to note that urban operations cannot be stopped for a long time and cities cannot be neglected. The more we understand how cities can cope with such events, the more we can improve their resilience and support city management (Cheshmehzangi, 2020: 35).

\subsection{Conclusion of theory}

Resilience is a concept that is fundamentally concerned with how a system, society, and individual face disruption and changes (Mitchel. T., Katie. H., 2012). Urban resilience is defined as "the capacity of damaged communities or ecosystems to digest and repair negative effects" (Birkmann, Cardona, et al., 2013) because today, urban spaces can best play the role of centers of collective life (Cheraghi et al., 2013: 5).

Urban resilience has four main dimensions: 1) Economic: the response and adaptation of individuals and communities so that they can reduce the potential damages caused by accidents; 2) Social: it is obtained from the difference between social capacities in reacting positively, adapting to changes, and maintaining adaptive behavior and recovering from accidents; 3 ) Physical: an examination of physical and infrastructure systems such as pipelines and roads as well as their dependence on other infrastructures; 4) Institutional-managerial: it contains features related to risk reduction, planning and experiences of previous accidents and through the capacity of communities to reduce risk, the employment of local people is affected in reducing risk (Maleki et al., 2018: 7).

Urban resilience tools and measures are essential to respond to the problems and challenges_that we anticipate and do not anticipate. Pandemics appear to be an example of specific events that can be harmful in different ways and can increase the burden of managing the entire city. In such cases, this widespread vulnerability affects multiple functions of cities. The prevalence of any disease indicates the uncertain situation of the city. This is unhealthy for the government, institutions, economy, health, and most importantly, the community (Cheshmehzangi, 2020: 9).

\section{Review Of Literature}

Pandemics are diseases that affect a significant portion of the population. If these diseases spread rapidly to other countries or continents, they are also called global pandemics.

Throughout history, pandemics have had a profound effect on societies, both economically and culturally, and socially. The plague of Justinian, which broke out $500 \mathrm{BC}$, can be called the first pandemic. The latest is the Corona Virus, which now almost every country in the world is struggling with it.

Studying the pandemics before the outbreak of Covid-19 will help a lot in how to deal with this new virus as well as its management nationally and globally. Thus, the table below shows a summary of the pandemic dates, the number of

Page 10/18 
individuals and countries affected, and mortality rates of the pandemics or epidemics throughout history (source: authors).

Table 4: An overview of the pandemics or epidemics throughout history

\begin{tabular}{|llll|}
\hline $\begin{array}{l}\text { Type of } \\
\text { pandemic }\end{array}$ & Pandemic date & Affected regions in the world & Mortality \\
\hline $\begin{array}{l}\text { Plague of } \\
\text { Justinian }\end{array}$ & 541 to $750 \mathrm{AD}$ & $\begin{array}{l}\text { Byzantine Empire (Eastern Rome) and } \\
\text { Sassanid Empire }\end{array}$ & $\begin{array}{l}25 \text { million people } \\
\text { (13 to 26 percent of the world's population) }\end{array}$ \\
\hline $\begin{array}{l}\text { Black } \\
\text { plague }\end{array}$ & 1340 to $1351 \mathrm{AD}$ & Eastern lands and throughout Europe & About 200 million people \\
\hline Smallpox & $\begin{array}{l}\text { 15th to } 17 \text { th } \\
\text { centuries AD }\end{array}$ & The United States & $\begin{array}{l}\text { About 20 million people (equivalent to } 90 \% \\
\text { of the US population) }\end{array}$ \\
\hline Cholera & 1817 to $1823 \mathrm{AD}$ & India and neighboring countries & 7 million people \\
\hline Spanish flu & 1918 to $1919 \mathrm{AD}$ & All over the world & 50 million people \\
\hline SARS virus & 2002 to $2003 \mathrm{AD}$ & China and 26 other countries & 774 people \\
\hline Swine flu & 2009 to $2010 \mathrm{AD}$ & The United States & 248,500 people \\
\hline Ebola virus & 2014 to $2016 \mathrm{AD}$ & Africa & 11,325 people \\
\hline
\end{tabular}

Source: authors, 2020

\section{Results And Discussions}

\subsection{Extraction and analysis of the criteria and sub-criteria}

To conceptualize and classify the experimental and field studies conducted on identifying the factors affecting urban resilience in different dimensions, as well as to determine the citizens' behavior and officials' crisis management in an epidemic such as Covid-19 throughout cities, and especially Tehran, and to examine as closely as possible the relationship between urban resilience and Covid-19, which has changed all the existing relationships in cities around the world from early 2020 to the present day in 2021, the present study sought to extract the urban development criteria related to resilience against the epidemic in physical, economic, social and welfare dimensions as well as governance and management. Therefore, relying on documentary and field studies, several criteria along with related sub-criteria, each of which has a positive or negative orientation, were achieved. To achieve the objectives of the present study and to determine the significance of each of the criteria extracted in the issue of urban resilience against Corona Virus, a pairwise comparison or L-hour questionnaire was designed by the authors to compare the significance of several sub-criteria in each dimension. 16 experts of urban sciences including experts in urban development, urban planning, and urban design completed the questionnaire. The results of the experts' questionnaires were analyzed by AHP hierarchical method using EXPERT CHOICE software and the score and significance of each sub-criterion were calculated the results of which can be seen in the score column in the following table. It should be noted that the sum of the weights of the sub-criteria in each general criterion is equal to one which indicates the normality of the weight of the sub-criteria to continue the study.

Table 5: Criteria and indicators 


\begin{tabular}{|c|c|c|c|c|}
\hline Dimensions & Indicators & Criteria & Orientation & Score \\
\hline \multirow[t]{9}{*}{$\begin{array}{l}\text { Physical } \\
\text { dimension }\end{array}$} & \multirow[t]{7}{*}{$\begin{array}{l}\text { Transportation } \\
\text { infrastructure }\end{array}$} & $\begin{array}{l}\text { Capacity, safety, reliability, integration } \\
\text { (connectivity), and transport efficiency }\end{array}$ & + & 0.592 \\
\hline & & Affordability of the public transportation & + & 0.408 \\
\hline & & $\begin{array}{l}\text { Access to basic needs and services at different } \\
\text { stages (food, water, shelter, energy, health, } \\
\text { education) }\end{array}$ & + & 0.372 \\
\hline & & $\begin{array}{l}\text { Public spaces and public facilities (for recreation, } \\
\text { physical activity, etc.) }\end{array}$ & + & 0.101 \\
\hline & & Mixed development & + & 0.114 \\
\hline & & The ratio of high-risk areas to population density & + & 0.208 \\
\hline & & $\begin{array}{l}\text { The ratio of high-risk areas to the area of sensitive } \\
\text { sub-uses }\end{array}$ & + & 0.205 \\
\hline & \multirow{2}{*}{$\begin{array}{l}\text { Possibility of rapid and } \\
\text { correct reconstruction } \\
\text { and repair }\end{array}$} & $\begin{array}{l}\text { Ensuring access to basic services for all and } \\
\text { providing support services after disasters }\end{array}$ & + & 0.656 \\
\hline & & Existence of plans to deal with possible crises & + & 0.344 \\
\hline \multirow[t]{5}{*}{$\begin{array}{l}\text { Economic } \\
\text { dimension }\end{array}$} & \multirow[t]{2}{*}{ Structure } & $\begin{array}{l}\text { Job density (proximity to housing and work and } \\
\text { the transportation area) }\end{array}$ & + & 0.287 \\
\hline & & $\begin{array}{l}\text { Income (equality, multiple sources, ...), the poverty } \\
\text { rate }\end{array}$ & + & 0.713 \\
\hline & \multirow[t]{3}{*}{ Security and stability } & $\begin{array}{l}\text { Insurance (internal and external) and social } \\
\text { welfare }\end{array}$ & + & 0.611 \\
\hline & & $\begin{array}{l}\text { Stability of prices and incomes, the value of } \\
\text { properties }\end{array}$ & + & 0.286 \\
\hline & & $\begin{array}{l}\text { Tax reduction rate to deal with the effects of the } \\
\text { shock }\end{array}$ & + & 0.103 \\
\hline \multirow{10}{*}{$\begin{array}{l}\text { Social and } \\
\text { welfare } \\
\text { dimension }\end{array}$} & \multirow{2}{*}{$\begin{array}{l}\text { Socio-economic } \\
\text { characteristics }\end{array}$} & House ownership & + & 0.370 \\
\hline & & $\begin{array}{l}\text { Various individual skills (to mobilize skills in times } \\
\text { of disaster) }\end{array}$ & + & 0.630 \\
\hline & \multirow{2}{*}{$\begin{array}{l}\text { Community bonds, } \\
\text { support, and social } \\
\text { institutions }\end{array}$} & $\begin{array}{l}\text { Empowerment and employment of vulnerable } \\
\text { groups, social security mechanisms }\end{array}$ & + & 0.723 \\
\hline & & $\begin{array}{l}\text { Civic and voluntary participation in social } \\
\text { networks }\end{array}$ & + & 0.277 \\
\hline & \multirow[t]{6}{*}{ Security and welfare } & People's physical and psychological health & + & 0.146 \\
\hline & & Preventive measures to maintain health & + & 0.297 \\
\hline & & Responsive health measures & + & 0.238 \\
\hline & & Undefended urban spaces & - & 0.127 \\
\hline & & Number of working children & - & 0.107 \\
\hline & & Number of false jobs & - & 0.085 \\
\hline \multirow{3}{*}{$\begin{array}{l}\text { Governance and } \\
\text { management } \\
\text { dimension }\end{array}$} & \multirow{2}{*}{$\begin{array}{l}\text { Leadership and } \\
\text { participation }\end{array}$} & Strong leadership & + & 0.392 \\
\hline & & Transparency, accountability, corruption, etc. & + & 0.608 \\
\hline & Resource management & $\begin{array}{l}\text { Effective resource management (funds, personnel, } \\
\text { etc.) }\end{array}$ & + & 0.372 \\
\hline
\end{tabular}

Page 12/18 


\begin{tabular}{|c|c|c|c|}
\hline & Skilled personnel and emergency experts & + & 0.309 \\
\hline & $\begin{array}{l}\text { Population with emergency and recovery skills } \\
\text { (first aid, etc.) }\end{array}$ & + & 0.319 \\
\hline \multirow{5}{*}{$\begin{array}{l}\text { Contingent planning, } \\
\text { emergency, and } \\
\text { recovery }\end{array}$} & $\begin{array}{l}\text { Integration of risk reduction and resilience in } \\
\text { development plans and policies }\end{array}$ & + & 0.207 \\
\hline & Recovery and repair speed & + & 0.123 \\
\hline & $\begin{array}{l}\text { The ongoing process of reviewing and monitoring } \\
\text { programs and evaluations }\end{array}$ & + & 0.189 \\
\hline & $\begin{array}{l}\text { Standard updated databases and integrated } \\
\text { planning, monitoring, and evaluation of actions }\end{array}$ & + & 0.200 \\
\hline & $\begin{array}{l}\text { Continuous and up-to-date risk assessment; } \\
\text { scenarios for another type of infrastructure and } \\
\text { services (costs, losses, etc.) }\end{array}$ & + & 0.281 \\
\hline \multirow[t]{2}{*}{$R \& D$} & Innovation and technology updating & + & 0.550 \\
\hline & $\begin{array}{l}\text { Allocation of funds and facilities for risk research } \\
\text { and academic collaboration }\end{array}$ & + & 0.450 \\
\hline
\end{tabular}

Sources: authors

\subsection{Examination of the correlation between criteria in different dimensions from the viewpoint of Tehran residents}

After determining the weight and significance of urban resilience criteria against Covid-19 as well as examining the level of satisfaction of Tehran citizens with them, the correlation between the four significant criteria from the authors' point of view, which have a great impact on urban life in four physical, economic, social, welfare, governance, and management dimensions, was analyzed using the correlation test with the help of SPSS 16 software, the results of which are shown in Table 6. The results of the correlation test that was performed for four criteria in the four studied dimensions show that the reliability of the correlation between the four selected criteria, namely land use and urban design in the physical dimension, security and stability in the economic dimension, community bonds, support, and social institutions in the social dimension, and welfare, as well as leadership and participation in the dimension of governance and management, is 99\%; and in all these cases the Pvalue or the same significance level is less than 0.05 , which indicates the significance of the pairwise relationships between the variables.

To describe the obtained correlation coefficients, it can be noted that there is a moderate correlation between the criteria of land use and urban design and security and stability; the criteria of security and stability and support and community bonds and social institutions; as well as leadership and partnership criteria and stability and security. Other pairwise correlations have weaker relationship intensity than the above.

\section{Table 6: Correlation test between the criteria}




\begin{tabular}{|c|c|c|c|c|c|}
\hline & & $\begin{array}{l}\text { Land use and } \\
\text { urban design }\end{array}$ & $\begin{array}{l}\text { Security } \\
\text { and } \\
\text { stability }\end{array}$ & $\begin{array}{l}\text { Community bonds, support, } \\
\text { and social institutions }\end{array}$ & $\begin{array}{l}\text { Leadership } \\
\text { and } \\
\text { participation }\end{array}$ \\
\hline \multirow[t]{3}{*}{ Land use and urban design } & $\begin{array}{l}\text { Pearson } \\
\text { Correlation }\end{array}$ & 1 & $.477^{\star \star}$ & $.392^{\star \star}$ & $.390^{\star \star}$ \\
\hline & $\begin{array}{l}\text { Sig. }(2- \\
\text { tailed) }\end{array}$ & & .000 & .000 & .000 \\
\hline & $\mathrm{N}$ & 120 & 120 & 120 & 120 \\
\hline \multirow[t]{3}{*}{ Security and stability } & $\begin{array}{l}\text { Pearson } \\
\text { Correlation }\end{array}$ & $.477^{\star \star}$ & 1 & $.496^{\star \star}$ & $.426^{\star \star}$ \\
\hline & $\begin{array}{l}\text { Sig. }(2- \\
\text { tailed) }\end{array}$ & .000 & & .000 & .000 \\
\hline & $\mathrm{N}$ & 120 & 120 & 120 & 120 \\
\hline \multirow[t]{3}{*}{$\begin{array}{l}\text { Community bonds, support, } \\
\text { and social institutions }\end{array}$} & $\begin{array}{l}\text { Pearson } \\
\text { Correlation }\end{array}$ & $.392^{\star \star}$ & $.496^{\star \star}$ & 1 & $.359^{\star \star}$ \\
\hline & $\begin{array}{l}\text { Sig. }(2- \\
\text { tailed) }\end{array}$ & .000 & .000 & & .000 \\
\hline & $\mathrm{N}$ & 120 & 120 & 120 & 120 \\
\hline \multirow[t]{3}{*}{$\begin{array}{l}\text { Leadership and } \\
\text { participation }\end{array}$} & $\begin{array}{l}\text { Pearson } \\
\text { Correlation }\end{array}$ & $.390^{\star \star}$ & $.426^{\star \star}$ & $.359^{\star \star}$ & 1 \\
\hline & $\begin{array}{l}\text { Sig. }(2- \\
\text { tailed) }\end{array}$ & .000 & .000 & .000 & \\
\hline & $\mathrm{N}$ & 120 & 120 & 120 & 120 \\
\hline \multicolumn{3}{|c|}{ **. Correlation is significant at the 0.01 level (2- } & tailed) & & \\
\hline
\end{tabular}

\section{Conclusions}

Given that it has not been long since the onset of the Covid-19 pandemic, identification of the different dimensions of urban resilience against this global pandemic has many ambiguous and unknown dimensions. On the other hand, given that there are still many ambiguities and disagreements about the virus itself and its behavior, the ways to deal with Covid-19 and to improve urban resilience in the face of it are difficult. In the present study, given the concepts related to urban resilience, different dimensions and criteria of this concept were adapted based on the opinions of urban science experts and public satisfaction with the conditions and programs in Tehran to deal with Covid-19 damages in all economic, social and welfare, physical, governance, and management dimensions.

According to the research process and studies to develop urban development criteria with a focus on resilience against Covid19, 12 criteria and 36 sub-criteria in four physical, economic, social, and welfare, and governance and management dimensions were extracted and classified. Each of these sub-criteria had a positive or negative orientation and a separate score. The score or weight of each sub-criterion was determined using the AHP hierarchical analysis method and L-hour (pairwise comparison) questionnaire completed by 16 urban development professors and experts of urban management, consulting engineers, and urban contractors, using EXPERT CHOICE software. Finally, the sum of the scores of the sub-criteria showed normality of the weight of the criteria and their relative significance in the research stages. Then, a questionnaire was designed with a five-point Likert scale based on purposive sampling with a statistical population of 120 people selected randomly from among the residents of Tehran to measure the pairwise correlations between the four criteria of the four dimensions that have the greatest impact on citizens' lives. Using SPSS 16 software, reliability of the correlation between the four selected criteria, namely land 
use and urban design in the physical dimension, security and stability in the economic dimension, community bonds, support and social institutions in the social dimension and welfare as well as leadership and participation in the dimension of governance and management was $99 \%$. In all these cases the P-value or the same significance level is less than 0.05 , which indicates the significance of the pairwise relationships between the variables.

Finally, according to all the studies and examination of the criteria by urban development experts and professors as well as Tehran residents, it is concluded that during the Corona Virus pandemic, all four dimensions are equally important for urban resilience against this virus. Measures should be taken to increase the level of resilience in all these four dimensions and criteria. Examples of these measures are provided in the form of suggestions as follows:

- Creation and strengthening of the infrastructures required by a smart city

- Redesigning and widening busy spaces such as commercial areas

- Increasing the number of public vehicles such as subway wagons and buses to observe the social distance

- Designing pedestrian passages and public spaces for recreation and physical activity

- Designing and implementing programs for mixed development in neighborhoods for easy access to daily needs

- Promoting the ability and planning of officials to deal with and manage the crisis during a pandemic

- Upgrading health and hospital infrastructures to deal with risk

- Empowering the medical staff by anticipating their logical demands during the pandemic

\section{Declarations}

- The authors have approved ethics standards regarding manuscript production and they are consent to participate in preparing the manuscript and also agree with possible publication.

- Authors agree with availability of data and materials

- All authors certify that they have no affiliations with or involvement in any organization or entity with any financial interest or non-financial interest in the subject matter or materials discussed in this manuscript.

\section{References}

- Alberti, M. Marzluff, J. Shulenberger, G. Bradley, C. \& Zumbrunnen. (2003). Integration Humans into Ecology: Opportunities and Challenges for Studying Urban Ecosystems. BioSience, 169-179.

- Barrett,C.B.,\&Constas,M.A.(2014).Toward a theory of resilience for international development applications. Proceedings of National Academy of Sciences, 111(40), 14625-14630

- Birkmann, J., et al. (2013). "Framing vulnerability, risk and societal responses: the MOVE framework." Natural Hazards 67(2): 193-211.

- Ihekweazu, C., Basarab, M., Wilson, D., Oliver, I., Dance, D., George, R., et al. (2010). Outbreaks of serious pneumococcal disease in closed settings in the post-antibioticera:A systematic review. Journal of Infection, 61(1), 21-27.

- Paton D. and Johnston, D.2001. "Disasters and communities: vulnerabilities, resilience, and preparedness", Disaster Prevention and Management 10 (4) (2001), pp. 270-277.

- Siemens, Arup, \& RPA. (2013)Toolkit for Resilient Cities: Infrastructure, Technology and Urban Planning,60pages document. Retrieved January24,2020, from

https://assets.new.siemens.com/siemens/assets/public.1543066657.641ee2256c5a0d5919d1aa3094a701f6ec9c3f90.toolkitforresilient-cities.pdf. 
- Timmerman, P., 1981. Vulnerability, Resilience and the Collapse of Society: A Review of Models and Possible Climatic Applications. , Institute for Environmental Studies, University of Toronto, Canada.

- Vanolo, A. (2015). The Fordist city and the creative city: Evolution and resilience in Turin, Italy. City, Culture and Society, 6(3), 69- 74. Retrieved from: www.sciencedirect.com/science/article/ pii/S1877916615000041

- World Health Organisation (WHO). (2019). Health Emergency and Disaster Risk Management Framework. Geneva:

Switzerland

-Adger, W.N. (2000). Social and ecological resilience: Are they related? Progress in Human Geography, vol. 24, no.3, 347-364

-Agudelo-Vero, Claudia M.(2012). Harvesting urban resources towards more resilient cities.In Resources, Conversation and Recycling.

-Alexander, D. E. 2013. Resilience and disaster risk reduction: An etymological journey. Natural Hazards and Earth System Science, 13: 2707-2716. DOI:10,5194/nhess-13-2707-2013.

-Almedom, A. 2005. Resilience, hardiness, sense of coherence, and posttraumatic growth: all paths leading to light at the end of the tunnel?. Journal of Loss and Trauma, 10: 253-265. DOI:10,1080/15325020590928216.

-Arefi, M. (2014 .)Deconstructing Placemaking: Needs, Opportunities, and Assets, Routledge

-Ayling, J. 2009. Criminal organizations and resilience. International Journal of Law, Crime and Justice, 37:182-196.

DOI:10,1016/j.ijlcj.2009,10,003.

-Buckle .P, Graham. M and Syd S. 2000. "New approaches to assessing vulnerability and resilience", Australian Journal of Emergency Management 2000 (2000), pp. 8-14.

-Carlson, J. L., Haddenden, R. A., Bassett, G., Buehring, W. A., Collins, M. J., Folga, S., et al. (2012). Resilience: Theory and applications. Report Document, Report number ANL/DIS-12-1, Decision and Information Sciences Division.

-Cheraghi, Mehdi, Motie Langroodi, Seyed Hassan, Souri, Farshad (2011, spring), Sustainability analysis of the relationship between family exploitation system and food security in rural areas of Ghani Bigloo village of Zanjan; Human Geography Research, Vol. 48, No. 1, p. 197-209.

-Cheshmehzangi, A(2020).The city in need, Urban Resilience and City Management in Disruptive Disease Outbreak Events, springer, Germany

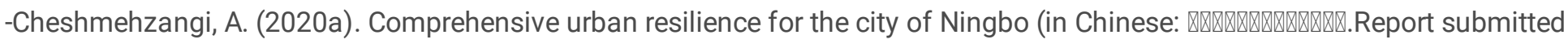
to local government units in February(2020), Ningbo, China

-Coaffee, J., \& Lee, P. (2016). Urban resilience (planning, environment, cities). Red Globe Press. Part of Macmillan International Higher Education.

-Coaffee,J.(2013).Towardsnext-generation urban resilience in planning practice: From securitization to integrated place making. Planning Practice \& Research, 28(3), 323-339.

-Fallah, Massoud, Mohammad, Massoud, and Assadollah, Navaie (2014), The role of designing flexible and resilient urban spaces in crisis management; The Fifth International Conference on Comprehensive Natural Crisis Management (INDM-2014), 2014, pp. 1354.

-Farzad Behtash, Mohammad Reza, Kei Nejad, Mohammad Ali, Pir Babaei, Mohammad Taqi, Asgari, Ali (2013), Evaluation and analysis of resilience dimensions and components in Tabriz metropolis; Journal of Fine Arts-Architecture and Urban Planning, pp. 33-42. 
-Folke, C. 2006. Resilience: the emergence of a perspective for social-ecological systems analyses. Global Environmental Change, 16, 253-267. DOI:10,1016/j.gloenvcha.2006,04,002

-Folke, C., et al. (2010). "Resilience thinking: integrating resilience, adaptability and transformability." Ecology and Society 15(4): 20.

-Garschagen, M. 2013. Resilience and organisational institutionalism from a cross-cultural perspective: an exploration based on urban climate change adaptation in Vietnam, Nat. Hazards, 67: 25-46. DOI:10,1007/s11069-011-9753-4.

-Godschalk, D. R. (2003), urban hazard mitigation: creating resilient cities. Natural hazards review, 4(3),136-143;

-Grimmond, S. 2007. Urbanisation and global environmental change: local effects of urban warming. The Geographical Journa,173:83-8. DOI: 10,1111/j.1475-4959,2007,232_3.x

-Hrudey, S. E., Huck, P. M., Payment, P., Gilham, R. W., \& Hrudey, E. J. (2002). Walkerton: Lessons learned in comparison with waterborne outbreaks in the developed world. Journal of Environmental Engineering and Science, 1(6), 397-407.

-Jabareen, Y. (2014). Planning the resilient city: Concepts and strategies for coping Planning the resilient city. Concepts and strategies for coping with climate change and environmental risk.

-King Christine, A. 2008. Community Resilience and Contemporary Agri-Ecological Systems: Reconnecting People and Food, and People with People, Systems Research and Behavioral Science, Syst.

-Kulig, J. 2000. Community resiliency: The potential for community health nursing theory development. Public Health Nursing, 17-5: 374-385. DOI: 10,1046/j.1525-1446,2000,00374.x.

-Maleki, Saeed, Mahmoud, Arvin, Shahram Bazr Afkan (2018), Examination of the role of good urban governance model in the realization of a resilient city: a case study of Ahvaz city; Journal of Urban Development Knowledge, No. 4.

-Martinelli, D., Gian Paolo, C. and Vesna,T., Stephen, M. 2014. Analysis of Economic Resiliency of Communities Affected By Natural Disasters: The Bay Area Case Study. 4th International Conference on Building Resilience, Building Resilience, Economics and Finance, 18: 959 - 968. DOI: 10,1016/S22125671(14)01023-5

-McEntire, D. A. (2014). Disaster response and recovery: strategies and tactics for resilience, John Wiley \& Sons.

-Meerow, S. \& Stults, M(2016). Comparing Conceptualizations of Urban Climate Resilience in Theory and Practice. Sustainability(8): 2-16.

-Mileti, D.S. (1999). Disasters by design: a reassessment of natural hazards in the United States, Natural hazards and disasters, Joseph Henry Press, Washington, DC.

-Mitchell, T., \& Harris, K. (2012). Resilience: A risk management approach. ODI Background Note. Overseas Development Institute: London;

-Parvin, G. A., Surjan, A., and Rahman, A., Shaw, R. 2016. Urban Risk, City Government, and Resilience,Urban Disasters and Resilience in Asia, Pages 21-34. DOI:10,1016/B978-0-12-802169-9,00002-1.

-Pelling, M. (2003). The Vulnerability of Cities: Natural Disasters and Social Resilience. London, Earthscan.

-Pizzo, B. 2015. problematizing resilience: Implications for planning theory and practice. Cities 43: 133- 140. DOI:10,1016/j.cities.2014,11,015.

-Rafieian, Mojtaba, Rezaei, Mohammad Reza, Asgari, Ali, Parhizgar, Akbar, Shayan, Siavash (2011, winter), Conceptual explanation of resilience and its indexing in community-based disaster management (CBDM) in space planning and 
landscaping, Modarres of Humanities, 15 (4), serial: 72, pp. 4-19.

-Rezaei, Mohammad Reza (2010), Explaining the resilience of urban communities to reduce the effects of natural disasters (earthquakes): a case study of Tehran metropolis, Ph.D. thesis in geography and urban planning, Tarbiat Modarres University, p. 27.

-Rezaei, Mohammad Reza (2014), Evaluation of economic and institutional resilience of urban communities against natural disasters: a case study of earthquakes in Tehran neighborhoods; Bi-Quarterly Scientific Research Journal of Crisis Management, No. 3, Spring and Summer, 2014, pp. 25-36.

-Sasanpour, Farzaneh, Musavand, Jafar (2010), The impact of man-made factors in exacerbating the consequences of natural hazards in metropolitan environments using fuzzy logic and GIS; Quarterly Journal of Geographical Research in Applied Sciences, Vol. 10, 16, pp. 29-50.

-Solecki, W., et al. (2011). "Climate change adaptation strategies and disaster risk reduction in cities: connections, contentions, and synergies." Current Opinion in Environmental Sustainability 3(3): 135-141.

-Turner, M. D. (2013). "Political ecology I An alliance with resilience?" Progress in Human Geography: 0309132513502770.

-UNHabitat.(2018).City Resilience Profiling Tool(CRPT). Retrieved January 28,2020,from http:// urbanresiliencehub.org/wpcontent/uploads/2018/02/CRPT-Guide.pdf.

\section{Supplementary Files}

This is a list of supplementary files associated with this preprint. Click to download.

- GraphicalAbstract21.jpg

- Highlights.docx 